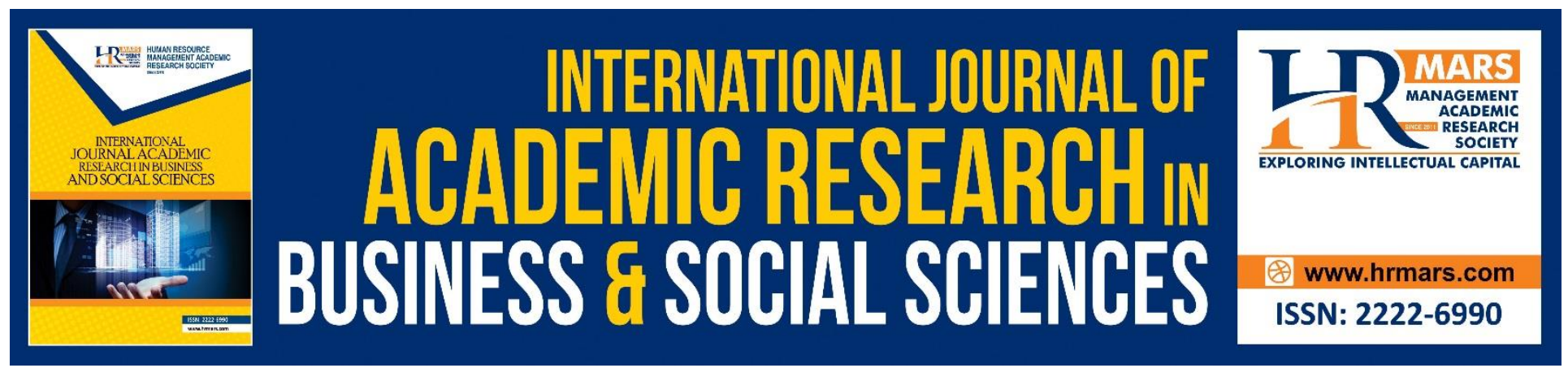

\title{
Education Zakat Distribution Practice in the Kedah Zakat Board: Analysis Towards the Maslahah and Social Principles
}

Mohamad Muhaimin Mohamad Zaki, Afnan Faiz Ridzuan Ahmad, Jasni Sulong

To Link this Article: http://dx.doi.org/10.6007/IJARBSS/v10-i7/7710

DOI:10.6007/IJARBSS/v10-i7/7710

Received: 07 April 2020, Revised: 14 May 2020, Accepted: 18 June 2020

Published Online: 27 July 2020

In-Text Citation: (Zaki, Ahmad, \& Sulong, 2020)

To Cite this Article: Zaki, M. M. M., Ahmad, A. F. R., \& Sulong, J. (2020). Education Zakat Distribution Practice in the Kedah Zakat Board: Analysis Towards the Maslahah and Social Principles. International Journal of Academic Research in Business and Social Sciences. 10(7), 883-903.

Copyright: @ 2020 The Author(s)

Published by Human Resource Management Academic Research Society (www.hrmars.com)

This article is published under the Creative Commons Attribution (CC BY 4.0) license. Anyone may reproduce, distribute, translate and create derivative works of this article (for both commercial and non-commercial purposes), subject to full attribution to the original publication and authors. The full terms of this license may be seen

at: http://creativecommons.org/licences/by/4.0/legalcode

Vol. 10, No. 7, 2020, Pg. 883 - 903

http://hrmars.com/index.php/pages/detail/IJARBSS

JOURNAL HOMEPAGE

Full Terms \& Conditions of access and use can be found at http://hrmars.com/index.php/pages/detail/publication-ethics 


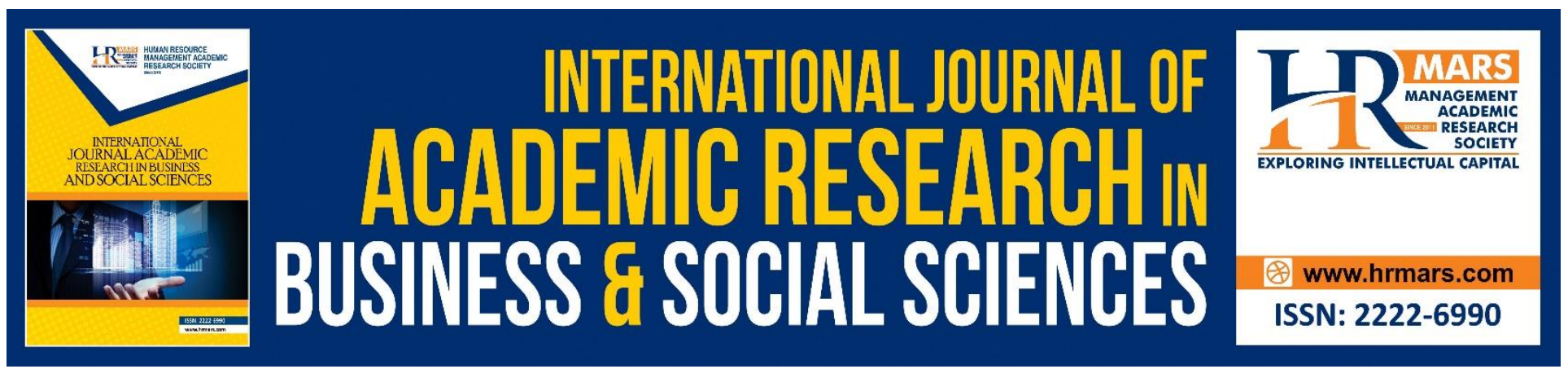

\title{
Education Zakat Distribution Practice in the Kedah Zakat Board: Analysis Towards the Maslahah and Social Principles
}

\author{
Mohamad Muhaimin Mohamad Zaki ${ }^{1}$, Afnan Faiz Ridzuan Ahmad², \\ Jasni Sulong ${ }^{3}$ \\ ${ }^{1} \mathrm{PhD}$, Candidate for Islamic Studies (Syariah), Center of Humanity Studies, Universiti Sains Malaysia, \\ ${ }^{2} \mathrm{PhD}$ Candidate for Islamic Studies (Syariah), Center of Humanity Studies, Universiti Sains Malaysia, \\ ${ }^{3}$ Assoc Professor, Islamic Studies Department, Center of Humanity Studies, Universiti \\ Sains Malaysia.
}

\begin{abstract}
Zakat is a Maliyah act of worship that involves the sharing among humans. In the distribution of zakat, the priority in a zakat institution is given to the development of human capital encompassing zakat for the education field. Additionally, the education sector is among the most important sector in the effort to develop the human capital by the government. Evidently, in the 2019 annual budget, the distribution for the education sector remains to be at the highest position which totaled RM60.2 billion or $19.1 \%$ from the entire government budget. However, simultaneously, there are a lot of people who are financially unfortunate so they face some difficulties in furthering their studies. The purpose of this study is to identify the method of distribution of the education zakat at the Lembaga Zakat Negeri Kedah (LZNK). Also, this paper discusses several maslahah principles applied by the LZNK when distributing the education zakat fund. This study adopts the qualitative research methodology by means of collecting the data through library study and site study using the interview method. Meanwhile, the data analysis method uses the inductive and deductive methods. Finally, the study finding will lead to the construction of the model and the conceptual framework of the education zakat distibution in the figh maslahah and social framework so that the role and sustainability of the education zakat are guaranteed and achieved.
\end{abstract}

Keywords: Practice, Distribution, Education Zakat, Usul Al-Fiqh, Maslahah.

\section{Introduction}

With the sophistication of the information technology that has become the mainstay in the industrial revolution 4.0, various methods of zakat distribution have been introduced by zakat institutions (Parid, 2001). In line with this, the total amount of zakat collection also recorded an improved performance in line with the economic growth among the Muslims today. Thus, zakat institutions play the role of distributing zakat fund fairly, transparently and efficiently to the asnaf. This is crucial 
because the zakat distribution is the second basic component in the zakat management (Adnan, et al, 2017).

However, the issue of society's confidence towards the zakat institutions is still plaguing the Muslims (Hairi et. al, 2012). It is irrefutable that zakat institutions are exposed to Muslims' general evaluation as it is an institution that is holding the public's trust. Among the issues that have always been debated are zakat fund misuse, the leaking committed by the amils assigned, mismanagement, and the persistent rates of poverty every year (Norazlina \& Abdul Rahim, 2013). The channeling of zakat fund must be distributed to eigh groups of asnaf as decided in At-Taubah verse 60 which means:

"Alms are for the poor and the needy, and those employed to administer the (funds); for those whose hearts have been (recently) reconciled (to Truth); for those in bondage and in debt; in the cause of Allah. and for the wayfarer: (thus is it) ordained by Allah, and Allah is full of knowledge and wisdom."

From the above verse, it can be summed up that the zakat fund can be distributed to asnaf poor and very poor, amil, mualaf, fisabilillah, gharimin, ibni sabil also riqab. The zakat fund distributed to these eight asnaf comes in various forms (Izam, 2010). There are education, social and economic developments, the development of religious institutions and the development of human capital (Shahir, 2007; Zaki \& Sulong, 2019).

The main objective of the zakat fund distribution according to Qaradawi (1973) is to increase the life values of the givers, cleansing and nurturing the assets, helping the people in need and strengthening social assurance. From the objectives aforementioned, clearly zakat is able to expand the assets and add to their blessings. In reality, the assets being under zakat mght be seen as lessening to the human eye, but in turn the benefit of zakat can increase the society's economic activity and continue to help the country to achieve the high-income status. (Zuhdi, 2003).

Thus, the societal development in terms of a better life, such as being released from the poverty, economic progress and education can be implemented using the zakat fund they receive (Buang, 2000; Zaki \& Sulong, 2019).

\section{Problem Statement}

Zakat scholars have been exposed to multiple issues and problems regarding the distribution of zakat. The first is that, the recording of zakat education distribution that is seen to be less efficient, leading to poor handling of the aid. As the implication, there are still a lot of asnaf out there who still do not receive zakat assistance (Rahman \& Anwar, 2014). Thus, Iman \& Sanep (2011) suggest that zakat institution management must be improved in terms of the collection and distribution seeing that zakat institutions are prominent institutions in the society. Thus, this institution must be in the know about the complaints, suggestions and even constructive criticisms so that the management can be improved from time to time.

This echoes the study done by Wahid et al. (2009). In the paper work, it is found that there is the leakage and fraud taking place among the distributors, causing zakat payers to feel dissatisfied. For example, in the study by Dahan (1998) there wee some negative cases happening such as misuse of power, zakat fraud and embezzlement at state level as reported to have happened in zakat institutions until people's trust is severely affected. Also, the failure of the institution in preparing its financial report also affects the sense of transparency in the management (Online, 2001). 
INTERNATIONAL JOURNAL OF ACADEMIC RESEARCH IN BUSINESS AND SOCIAL SCIENCES Vol. 10, No. 7, July, 2020, E-ISSN: 2222-6990 @ 2020 HRMARS

Most of the institutions in Malaysia were also not transparent in exposing the information in their websites (Faisol, Suhaina \& Zulkifli, 2009). Some of the esposures include cases about the transparency issue like transferring the zakat fund. This is related to its efficacy which is claimed to very inefficient and unprofessional in carrying out their duties. This statement is also harmonious with the work by Abdul Wahab et.al. (1995) where he agree that the distributors of zakat in Malaysia are not managed properly as there is a shortage of qualified workers and there is no professional networking.

The zakat institution's management is also often criticised due to bureaucracy (Aidit, 1989), the lack of efficacy in distributing the fund (Rahman et al., 2012; Hairunnizam et al., 2009; Mohd Asri, 2010; Fadly, 2010), and that it is not proactive (Abidin, 2010; Fadly, 2010). These comments invite further criticisms on the zakat institution's management (Abidin, 2010; Radiah, 2011; Sulong \& Ali, 2012). In effect, there emerges the lack of confidence on the part of the zakat payers towards the institution and this becomes the reason why an individual pays his zakat using a non-formal avenue (Aidit, 1989; Wahid et al, 2009; Abidin , 2009; Ahmad et al, 2005)

Of late, there are several issues and controversies that have plagued the zakat institution. One of the issues is the low level of belief of Muslims towards the institution. Every year, there will be complaints on the zakat institution reported in the media, especially related to he zakat distributor (Harzrul, 2010). Several researchers have also stressed on this issue, for example Wahid et al, (2009), Abidin, 2009; Ibrahim, 2008; Ahmad et al, 2005; Ahmad et al, 2006).

Ahmad et al. (2006) find that the majority of the respondents were dissatisfied with the zakat institution management although they did not pay any zakat to the institution. Apart from that, not being confident with the zakat institution are the reasons as to why an individual pays his zakat through a non-formal avenue (Wahid et al, 2009; Abidin, 2009; Ahmad, 2005).

Among the issues that are still hotly debated in the society is that there are still the poor and the very poor in high income states for example in Selangor and Federal Territory of Kuala Lumpur. A complex, time-consuming application process, and the eligibility of the asnaf to receive zakat are often raised (Abdul Latif, 1998). They need to fill in too many forms and have to undergo several complicated screening processes. The institution is also criticised for not being able to identify correctly the number of zakat recipients (Salleh, 2006). Bureaucracy and geographical scatter also impede an efficacious distribution. There are asnaf who reside in the end of a village and in very remote areas never once visited by zakat officers or the appointed representatives such as the Head of the Village or the mosque's committee member.

Therefore, zakat distribution method has to be revised to ensure maslahah to asnaf that is closely related to the things that are beneficial and prevent harm (Muhamad, 2013). This means that although the zakat distribution scope is stated in the al-Qur'an, the application of al-maslahah almursalah is a form of argument that is used when the terms and the laws are met and abided by (Mohamad, 2019).

In the education zakat distribution, maslahah used must be generic and contribute to the benefit of ummah. Thus, a mujtahid must be careful that maslahah that is to be the basis of the law should have a wide scope. As the impact, the maslahah does not only benefit some groups but it does not turn a blind eye to the other groups ('Abd Rahim, 2010). 
INTERNATIONAL JOURNAL OF ACADEMIC RESEARCH IN BUSINESS AND SOCIAL SCIENCES

Vol. 10, No. 7, July, 2020, E-ISSN: 2222-6990 @ 2020 HRMARS

Based on the three categories of maslahah namely daruriyyah, hajiyyah and tahsiniyyah as stated by As Syatibi (2005), this study will look into the role of these three categories in the education zakat distribution practice in Lembaga Zakat Negeri Kedah (LZNK) and next, form a conceptual framework of the zakat education distribution based on figh maslahah and the sosial aspect.

\section{The Background of Lembaga Zakat Negeri Kedah}

In Kedah Darul Aman, zakat administration was already established and this began since the 1930s. Based on the unfolding of the history, a certain Notice of Determination related to zakat was issued on 19 Jamadil Akhir 1355 or 5 September 1936. This was the same date that the office of Syeikhul Islam through Majmaul Syeikhul Islam joined by Haji Ismail bin $\mathrm{Hj}$ Mohd Saleh, Haji Yaakob bin $\mathrm{Hj}$ Ahmad and Haji Abdul Ghani bin Hj Awang. Majmaul Syeikhul Islam was officially established. This was to replace the position of Syeikhul Islam that began in 1901 (Lembaga Zakat Negeri Kedah, 2018). This notice was related to the order of collecting zakat fund from well-ff farmers after their paddy became ripe.

Zakat matters were the main thing that were focused by Majmaul Syeikhul Islam (some referred to him as Majma' Masyikhatil Islam) and these include how zakat was to be managed. The Riyal Zakat and Muslims' Donation in Kedah also noted that the year $1355 \mathrm{H}$ or $1936 \mathrm{M}$ was the year when paying zakat began to be announced officially to the people of Kedah. Although there are sources saying that it could be earlier, but an official note with respect to the establishment of a committee through the administrative law was dated $1355 \mathrm{H}$ or $1936 \mathrm{M}$.

Next, in 1955 two years before the independence of Malaya, theer was a complaint filed by the locals to Syeikhul Islam of Kedah, Syeikh Wan Sulaiman Bin Wan Sidek (1874-1935) with regard to the poor handling of zakat distribution. Thus, he had forwarded this issue to the Deputy Sultan at the time, DYTM Tengku Mahmud Ibnu Sultan Ahmad Tajudin (1876-1973). When asked what should be done to solve this issue, Syeikhul Islam answered, "this zakat mmust return to the person who is really qualified for the zakat, who is ulil amri in one particular place". He agreed to this, and ordered the public to hand over their zakat to the appointed amils only.

Initially, part of the zakat was released by the amil and the rest was up to the payers to give it to the other asnaf. Thus, in 1955 a zakat enactment was formulated (Enakmen Jabatan Zakat Negeri Kedah Darul Aman) where the paddy zakat must be paid by $100 \%$ or $8 / 8$ to the amil appointed.

Between 1984 and 1997, a representative of the ulil amri KDYMM Sultan Negeri Kedah Darul Aman appointed Dato' Syeikh Mahmood Naim as the Secretary to the Kedah Zakat Committee. He then expanded this zakat payment to all the fields of assets, where at first paddy zakat had transferred to asset zakat, right to income zakat and others deemed halal for an individual. Since then, the zakat collection performance has shown an encouraging increase every year.

Starting from 2015, the effort to continue to strengthen the Kedah zakat institution through improved zakat laws has been done progressively by the Kedah Zakat Commitee to ensure that a complete set of laws that not only covers the paddy zakat but also zakat for other assets. This continuous effort will finally be fruitful when the Lembaga Zakat Negeri Kedah Darul Aman (LZNK) Enactment was introduced to replace the diperkenalkan menggantikan Jabatan Zakat Negeri Kedah Darul Aman (JZNK) Enactment formulated in 1955. In the effort to strengthen the education zakat distribution, beginning in May 2018, Education and Distribution Innovation Department was created to replace the Distribution Office, Asnaf Development Department to further to amalgamate the education zakat distribution to the people or asnaf involved (Mazlan, 2019). 
INTERNATIONAL JOURNAL OF ACADEMIC RESEARCH IN BUSINESS AND SOCIAL SCIENCES

Vol. 10, No. 7, July, 2020, E-ISSN: 2222-6990 @ 2020 HRMARS

\section{The Education Zakat Distribution Method at Lznk}

There are various smethods of zakat education distribution carried out in LZNK (Mazlan, 2019). The distribution means that the zakat distribution from the collected zakat is reserved for those qualified recipients only. Thus, zakat institutions must ensure that the zakat distribution can be managed by shara and follow the guideline determined by syarak (Adnan et al, 2017).

Based on the 2019 Budget Report, published by LZNK, there are three main components divided in the distribution. The first is that the assistance to individuals comprising of students or the asnaf children who are studying in the universities (Bahri, 2017). The second is the aid to the religious institutions which are the center of human capital among the zakat asnaf. Both the main components in the zakat education distribution need to be managed effectively and systematically to leave an impact to the asnaf towards producing knowledgeable generations in the future (Ghazali, 2011; Qardhawi, 2010).

\section{(a) Assistance to Individuals}

Based on the report issued by LZNK, there are many forms of assistance given directly to individuals among asnaf, with the majority related to the fi sabilillah (Mazlan, 2019). This will automatically lighten the burden and increase their motivation especially those who cannot afford to study further to gain knowledge (Tamuri et al, 2006; Majid, 2003).

One form of the assistance is money aid for students who want to further studies to the public or private higher learning institutions in Malaysia. Student donation totalling RM 12,000.00 per person should enable them to study in Kolej Universiti Insaniah (KUIN) which is fully owned by the state, Kedah Darul Aman. The same donation is also channelled to asnaf children in Kedah who further their studies overseas like Egypt, Jordan, Syria, Yemen, Maghribi and Indonesia.

As the follow-up, to enhance the quality and development of the study of al-Qur'an dand to acknowledge Tahfiz Education in Kedah, assistance to students is also offered to students who are qualified. The same goes for students at the Sekolah Agama Rakyat (SAR) registered with Kedah Islamic Department through distribution of money for the exam fees and hostel food. Religious teachers with an income below RM1500 also receive this assistance from LZNK as a mark of appreciation for their ongoing services in spreading the teaching and knowledge of Islam.

Alongside the current development in the world of education that not only focuses on the studies in the religious field alone, LZNK also works actively in providing yearly assistance to medical students in the country and abroad, to produce more experts in the medical field. Such a move is consistent with the argument put forth by Abd. Khafildz (2011) that education is the mainstay to empower Islam. As of 2019, the zakat assistance given to students sponsored by LZNK follows their academic performance every semester and if they fail, the assistance will not be channelled to them (Mazlan, 2019).

In this vein, a lot of Muslims who have the opportunity to further their studies in the professional fields such as medical and technology do not have sufficient funds to do so, that the said fields are dominated by the non-Muslim experts. At par with the industrial revolutions 4.0 and the development of the fields of TVET, LZNK they also proactively give allowances to qualified industrial students. 
INTERNATIONAL JOURNAL OF ACADEMIC RESEARCH IN BUSINESS AND SOCIAL SCIENCES Vol. 10, No. 7, July, 2020, E-ISSN: 2222-6990 @ 2020 HRMARS

To increase the spirit of asnaf children to be more hardworking in their studies, other initiatives are given by LZNK such as the donations for students prior to their departure overseas especially for excellent students, through monthly allowances. Also, the flight tickets home are also provided to those who hve finished their studies and passed their examinations overseas. For poor students, assistance in the form of school necessities and hostel expenses is also provided. The list of avenues for the education zakat fund to these individuals is explained in detail in Table 1:

\begin{tabular}{|c|c|c|c|c|c|}
\hline No & DistributionTarget & $\begin{array}{l}\text { Actual } \\
\text { Spending for } \\
\text { Distribution In } \\
2017\end{array}$ & $\begin{array}{l}\text { Actual } \\
\text { Spending for } \\
\text { Distribution In } \\
2018\end{array}$ & $\begin{array}{l}\text { Estimated } \\
\text { Allocation in } \\
2019\end{array}$ & $\begin{array}{l}\text { Difference in } \\
\text { Estimation } \\
\text { for } \\
\text { Allocations } \\
\text { in } 2018 \text { and } \\
2019(\%)\end{array}$ \\
\hline 1 & $\begin{array}{l}\text { Donations for Local } \\
\text { Public and Private } \\
\text { Higher Learning } \\
\text { Institutions }\end{array}$ & $20,150,300.00$ & $18,9600,400.00$ & $17,700,000.00$ & $0 \%$ \\
\hline 2 & $\begin{array}{l}\text { KUIN Donation } \\
\text { *converted to } \\
\text { UNiSHAMS } \\
\text { scholarship in } 2018 \text {. }\end{array}$ & $1,200,000.00$ & $1,200,000.00$ & $2,400,000.00$ & $100 \%$ \\
\hline 3 & $\begin{array}{l}\text { Donations for } \\
\text { graduates overseas } \\
\text { (Egypt) }\end{array}$ & $3,360,000.00$ & $2,922.000 .00$ & $3,040,000.00$ & $87 \%$ \\
\hline 4 & $\begin{array}{l}\text { Donations for } \\
\text { graduates overseas } \\
\text { (Jordan) }\end{array}$ & $329,000.00$ & $188,000.00$ & $950,000.00$ & $32 \%$ \\
\hline 5 & $\begin{array}{l}\text { Donations for } \\
\text { graduates overseas } \\
\text { (Yemen) }\end{array}$ & $5,000.00$ & $50,000.00$ & $50,000.00$ & $0 \%$ \\
\hline 6 & $\begin{array}{l}\text { Donations for } \\
\text { graduates oversea } \\
\text { (Maghribi) }\end{array}$ & - & $24,000.00$ & $70,000.00$ & - \\
\hline 7 & $\begin{array}{l}\text { Donations for } \\
\text { graduates oversea } \\
\text { (Indonesia) }\end{array}$ & $615,000.00$ & $591,000.00$ & $560,000.00$ & $27 \%$ \\
\hline 8 & $\begin{array}{l}\text { Assistance for } \\
\text { students of Maahad } \\
\text { Tahfiz }\end{array}$ & $155,220.00$ & - & - & - \\
\hline 9 & $\begin{array}{lr}\text { Assistance } & \text { for } \\
\text { Nidzomi } & \text { School } \\
\text { Exam Fees } & \end{array}$ & $49,875.00$ & & & \\
\hline
\end{tabular}


INTERNATIONAL JOURNAL OF ACADEMIC RESEARCH IN BUSINESS AND SOCIAL SCIENCES Vol. 10, No. 7, July, 2020, E-ISSN: 2222-6990 @ 2020 HRMARS

\begin{tabular}{|c|c|c|c|c|}
\hline $\begin{array}{lr}\text { Assistance } & \text { for } \\
\text { Nidzomi } & \text { School } \\
\text { Food Fees } & \end{array}$ & $1,196,100.00$ & - & - & - \\
\hline $\begin{array}{l}\text { Asistance for public } \\
\text { and village religious } \\
\text { schools }\end{array}$ & $3,196,850.00$ & $2,622,000.00$ & $4,344,000.00$ & $66 \%$ \\
\hline $\begin{array}{l}\text { Medical Students } \\
\text { Scholarships (Local) }\end{array}$ & $1,994,950.00$ & $2,325,000.00$ & $2,393,500.00$ & $3 \%$ \\
\hline $\begin{array}{l}\text { Medical Students } \\
\text { Scholarships } \\
\text { (Overseas) }\end{array}$ & $3,450,123,14$ & $3,600,000.00$ & $2,745,000.00$ & $-24 \%$ \\
\hline $\begin{array}{l}\text { Allowance for } \\
\text { Industrial Students }\end{array}$ & & $500,900.00$ & $200,000.00$ & $-60 \%$ \\
\hline $\begin{array}{l}\text { Excellent Students } \\
\text { Scholarship } \\
\text { (Monthly) }\end{array}$ & - & $396,000.00$ & $972,000.00$ & $125 \%$ \\
\hline $\begin{array}{l}\text { Assistance for } \\
\text { Overseas Trip Fares }\end{array}$ & $162,000.00$ & $240,000.00$ & $180,000.00$ & $-25 \%$ \\
\hline $\begin{array}{l}\text { Assistance for } \\
\text { School Necessities }\end{array}$ & $2,280,500.00$ & $500,000.00$ & $600,000.00$ & $20 \%$ \\
\hline $\begin{array}{l}\text { Donations for Pre- } \\
\text { Higher Learning } \\
\text { Overseas Students }\end{array}$ & & $459,000.00$ & $420,000.00$ & \\
\hline
\end{tabular}

Table 1: Chanelling the education zakat fund to individuals

Based on Table 1, the exam fees assistance to Sekolah Agama Rakyat (SAR) in 2018 and 2019 is not channelled by LZNK because the aid is converted into direct conttributions to the schools involved (refer to Table 2). Meanwhile, for the industrial students' allowance (monthly) and the early donation for students going overseas the money will be channelled to them in 2018. This accounts for the current economy due to the increasing study costs.

\section{(b) Assistance to Educational Institutions}

As the effort to amalgamate the Islamic education institution as the epitome of the religion, LZNK also channels a provision to the institutions' administration. This will facilitate their administrative tasks effectively and systematically. This is an important step because the government also allocates a great budget to the education sector every year. For example, the Malaysian government has allocated 64.1 billion in 2020 and 60.2 billion in 2019. This figure of allocation is seen to hae increased to 3.9 billion to the Ministry of Education for education purposes. This goes to show that education is the main asset that can help spur the development of the country. 
INTERNATIONAL JOURNAL OF ACADEMIC RESEARCH IN BUSINESS AND SOCIAL SCIENCES

Vol. 10, No. 7, July, 2020, E-ISSN: 2222-6990 @ 2020 HRMARS

There are many kinds of aid and assistance that are offered to education institutions. However, this does not apply to all institutions. Only those registered with JAIK and not getting any assistance from the government will be considered to get this education zakat fund (Mazlan, 2019).

Among the institutions that receive this zakat distribution is the Nidzomi Religious School which was re-established in 2019 after it did not get any assistance in 2018. The fund is also dedicated to institutions that become the center of knowledge and activities like mosques, musollas and religious schools also education institutions under LZNK. As an instance, Pondok Moden Zakat or loosely translated as Zakat Modern Hut located in Alor Setar and two Maahad Dini Sultan Abdul Halim in Alor Setar and Sik are currently declared as the zakat-oriented schools fully governed by LZNK (Mazlan, 2019).

To elevate the status of turath (tradisi) and pondok study in Kedah, LZNK also spared some allocation to Ruwaq Jawi in Egypt and assistance to registered 'hut' institutions in Kedah Darul Aman. This is because Ruwaq Jawi is the center of study for students from Universiti Al-Azhar from the Archipelago and there are many students from Kedah studying in Universiti Al-Azhar come here to gain knowledge and study about the religion in further detail. It was established in 2015 as the brainchild of the Egypt's Mufti at the time, Dr Ali Jum'ah who suggested to some Malaysian students to propose to the Malaysian Embassy in Egypt to make a special building to replace the ruwaq in the Al-Azhar Mosque that no longer operated (Harian, 2017). The welfare of poor orphans is also not neglected by LZNK. Through the establishment of the Zakat Orphanage, students from among asnaf children are also assisted so that they can continue to study safely and comfortably.

Looking at the converts' educational needs, as they require training and some religious guidance, Pusat Bimbingan dan Latihan Saudara baru (PUSBA) or Converts' Guidance and Training Center is set up in Sungai Petani, Kedah. There are two forms of assistance channelled namely for the development for improvement purposes and the management that encompasses allowance and training to the converts.

Other than that, the allocation for the Al Qur'an, Fardhu Ain Classes (KAFA) at District level and the Asnaf Development Complex Management also two more new allocations are created which is the zakat daei intensive program and zakat volunteers that are introduced beginning in 2019. All these new aids are introduced by LZNK to see the suitability and current requirement that is suitable with the increasing management costs. A clearer explanation on the channeling of education zakat fund to institutions by LZNK is provided in Table 2: 
INTERNATIONAL JOURNAL OF ACADEMIC RESEARCH IN BUSINESS AND SOCIAL SCIENCES Vol. 10, No. 7, July, 2020, E-ISSN: 2222-6990 @ 2020 HRMARS

\begin{tabular}{|c|c|c|c|c|c|}
\hline No & Distribution target & $\begin{array}{l}\text { Actual } \\
\text { spending for } \\
2017\end{array}$ & $\begin{array}{l}\text { Actual } \\
\text { spending for } \\
2018\end{array}$ & $\begin{array}{l}\text { Estimated } \\
\text { allocation for } \\
2019\end{array}$ & $\begin{array}{l}\text { Difference of } \\
\text { estimated } \\
\text { allocation } \\
\text { between } 2018 \\
\text { and } 2019(\%) \\
\end{array}$ \\
\hline 1 & $\begin{array}{lr}\text { Assistance } & \text { for } \\
\text { Sekolah } & \text { Agama } \\
\text { Nidzomi } & \end{array}$ & $548,100.00$ & $2,096,400.00$ & $2,500.00 .00$ & (reestablished) \\
\hline 2 & $\begin{array}{l}\text { Construction of } \\
\text { mosque, surau and } \\
\text { religious schools }\end{array}$ & $5,919.783,97$ & - & $3,000,000.00$ & (restablished) \\
\hline 3 & $\begin{array}{l}\text { Construction of } \\
\text { Zakat Orphanage }\end{array}$ & - & $19,000,000.00$ & $14,000,000.00$ & $-26 \%$ \\
\hline 4 & $\begin{array}{l}\text { Assistance to Hut } \\
\text { Institutions }\end{array}$ & - & $1,086,500.00$ & $1,843,000.00$ & $+17 \%$ \\
\hline 5 & $\begin{array}{l}\text { Sponsorship for } \\
\text { Ruwaq Jawi }\end{array}$ & - & - & $300,000.00$ & - \\
\hline 6 & Zakat Modern Hut & - & $1,300,000.00$ & $2,200,000.00$ & $214 \%$ \\
\hline 7 & Maahad Ad Dini & - & $4,000.843 .70$ & $4,300.000 .00$ & $8 \%$ \\
\hline 8 & $\begin{array}{l}\text { Guidance and } \\
\text { Training Center for } \\
\text { Converts (PUSBA) }\end{array}$ & $1,000,000.00$ & $1,000,000.00$ & $2,000,000.00$ & $100 \%$ \\
\hline 9 & $\begin{array}{l}\text { Expenditure for } \\
\text { PUSBA }\end{array}$ & - & $150,000.00$ & $150,000.00$ & - \\
\hline 10 & $\begin{array}{ll}\text { Provision } & \text { for } \\
\text { District KAFA } & \\
\end{array}$ & - & - & $120,000.00$ & - \\
\hline 11 & $\begin{array}{l}\text { Complex of Asnaf } \\
\text { Development }\end{array}$ & - & - & $2,000,000.00$ & - \\
\hline 12 & $\begin{array}{l}\text { Zakat Daie } \\
\text { Incentive Program }\end{array}$ & - & - & $1,000,000.00$ & - \\
\hline 13 & Zakat Volunteers & - & - & $300,000.00$ & - \\
\hline 14 & $\begin{array}{l}\text { Education } \\
\text { Development } \\
\text { Program } \\
\end{array}$ & & $200,000.00$ & $700,000.00$ & $+350 \%$ \\
\hline 15 & $\begin{array}{l}\text { Special project- } \\
\text { Pulau Island } \\
\text { Education } \\
\text { Development }\end{array}$ & - & - & $25,000.00$ & - \\
\hline 16 & $\begin{array}{l}\text { Special project-CEO } \\
\text { @ School }\end{array}$ & - & - & $19,900.00$ & - \\
\hline
\end{tabular}

Table 2: Chaneling the education zakat distribution fund to institutions 
INTERNATIONAL JOURNAL OF ACADEMIC RESEARCH IN BUSINESS AND SOCIAL SCIENCES Vol. 10, No. 7, July, 2020, E-ISSN: 2222-6990 @ 2020 HRMARS

Based on Table 2, there are several forms of new chanelling in the distribution of education zakat fund beginning from 2018 such as a financial assistance to a registered religious hut schools, construction of orphanage, sponsorship of Ruwaq Jawi in Cairo, Egypt. Other than that, help is also relayed to the Zakat Modern Hut, Guidance and Training Center for Converts (PUSBA) in Sungai Petani, provision for Religious and Fadhu Ain Classes (KAFA) in every district, LZNK Asnaf Development Complex.

To increase academic excellence among the asnaf children, several programs are created for example the Program Insentif Daei Zakat, Sukarelawan Zakat, Program Pembanggunan Pendidikan, Projek Pembanggunan Pendidikan Pulau Tuba, Langkawi dan Program CEO @ School to produce more credible students, those who can think creatively and critically also competing constructively between one another lain (Mazlan, 2019).

\section{The Principle of Maslahah in the Formulation of Zakat}

Zakat formulation carries several kinds of maslahah. According to Ibn Qayyim (2001) the laws enacted by Allah SWT aim to protect the wellbeing of the people be it in this world or in the hereafter. They have their own blessings and 'illah and they do not go to waste. Maslahah realised from this formulation can be in these categories- daruriyyah, hajiyyah and tahsiniyyah (Al-Shatibi, 2011).

Al-Izz bin 'Abd al-Salam (t.t.) has included zakat in the category of acts of worship containing maslahah in this world and in the Hereafter. He also asserted that zakat is an act of worship that the benefit is known and it is not merely ta'abbud. According to al-Qardawi (1973) zakat although said to be attached to solat in the al-Quran, the fact is that zakat is not only mahdah of ta'abbud attribute. Zakat is included in the category of muamalat or the matter of customs related to the assets and properties of the muslimin. Other than that, zakat also encompasses the relationship with the asset owners and the development of a country and the poor, where all of these are intertwined with the society.

Among the zakat maslahah acknowledged by shara' included in the category of maslahah mu'tabarah is that muslim doing zakat will gain maslahah which is ukhrawi and they will be getting the greatest reward from Allah SWT and safe from Hell. An example would be helping Muslims further their studies and from this aid, more academicians and scholars in various branches of knowledge can be produced (Khalaf, 1996). Allah SWT had decreed which means:

Those who believe, and do deeds of righteousness, and establish regular prayers and regular charity, will have their reward with God: on them shall be no fear, nor shall they grieve (Al-Baqarah 2: 277)

Other than that, the enactment of zakat also contains maslahah ma'nawiyyah. According to alRaysuni (2014), maslahah ma'nawiyyah is the goodness related to the heart and it is characteristically spiritual. Some include the practice of zakat for a Muslim individual that can clear off the sin and cast away the mazmumah like being greedy and stingy. They will be used to mahmudah such as being generous and helping the poor and the needy. Other than that, individual assets that are laden with zakat are also clear from haram element and shubhat. This is because in one's assets, there are also some for the poor, whether for those who are begging for it, or otherwise (al-mahrum). 
INTERNATIONAL JOURNAL OF ACADEMIC RESEARCH IN BUSINESS AND SOCIAL SCIENCES

Vol. 10, No. 7, July, 2020, E-ISSN: 2222-6990 @ 2020 HRMARS

According to Qatadah and al-Zuhri, al-mahrum refers to a poor person but he is not asking around for money at the expense of dignity so that he will not be seen as humiliating (Al-Sabuni, 2002). The asset cannot be eaten and used fully by the owner. This is in line with the decree of Allah in the Quran al-Taubah 9: 103; al-Dhariat 51:19; hadith Riwayat Abu Daud No hadith 1665).

Other than that, the enactment of zakat also contains maslahah madiyyah which is maslahah that is materialistic and the luxuries can be felt by senses. This Maslahah will bring people away from adversaries, starvation, sadness and pain (Al-Raysuni, 2014). According to Mujahid (t.t), all the assets with value when being spent, the individual does not need to worrys the sustenance has been decided by Allah SWT. Their assets will not be lessened because people practise zakat. They will also obtain rewards after rewards during their lives in this world (Al-Sabuni, 2002).

All these maslahah are included in the maslahah mu'tabarah which is the maslahah that stays consistent with the al-Quran, Sunnah and ljmak. According to Khalaf (1996), maslahah achieved from the implementation of the laws as dictated by Allah SWT like zakat is maslahah mu'tabarah.

\section{Maslahah Daruriyyah in the Education Zakat Distribution Practice}

Maslahah daruriyyah is the maslahah that must be achieved by every individual for the sake of the wellbeing in our religion and to ensure life sustainability. This is the basic right for all humans. Chaos will affect human life and they will no longer be able to enjoy life's beauty when that maslahah is absent (al-Shatibi, 2011). Maslahah daruriyyah comprises of five main aspects (daruriyyat al-khams) namely the preservation of religion, life, mind, generation and assets (Al-Ghazali, 1971). There are also the fuqaha who have included the preservation of one's dignity under the scope of generational debate. Others have included this in an exclusive debate, simultaneously making maslahah daruriyyah carry six important elements (daruriyyat al-sitt) (Ismail, 2017).

Lembaga Zakat Negeri Kedah really emphasises on the aspect of mas/ahah for the preservation and sanctity of Islam in the education zakat distribution practice. Students who learn Islam in academic courses are responsible in ensuring that Islam continues to be preserved from any kinds of changes. They will also promote and spread the teaching of the religion (dakwah) to the local people after they finish their studies and return to Malaysia (al-Yubi, 1989). Thus, various schemes of zakat aid to individuals have been introduced including furthering studies to Egypt, Jordan, Yemen, Maghribi and Indonesia. LZNK had allocated for 2019 a total of RM4,670,000.00 to the students involved (Lembaga Zakat Negeri Kedah, 2019).

LZNK also introduced Full Scholarship to students who want to further studies at Bachelor degree and Diploma levels full time at UniSHAMS. LZNK targeted to allocate in 2019 a total of RM2,400,000.00 to students who furthered their studies at UniSHAMS. Public and village religious schools also received assistance from LZNK with an allocation of RM4,344,000.00 in 2019 (Lembaga Zakat Negeri Kedah, 2019). The move taken by LZNK in preparing great allocations in this category due to the maslahah of upholding religion stays at the highest position and overcomes all other maslahah lain in the daruriyyat al-khams according to the general consensus of the fuqaha (al-Amidi, 1980). 
INTERNATIONAL JOURNAL OF ACADEMIC RESEARCH IN BUSINESS AND SOCIAL SCIENCES Vol. 10, No. 7, July, 2020, E-ISSN: 2222-6990 @ 2020 HRMARS

Another initiative is also taken by LZNK to preserve the morality of the new Muslims in introducing aids to the institution. The estimated allocation in 2019 totalling RM2,000,000.00 will be channelled to Pusat Bimbingan dan Latihan Saudara Baru (PUSBA). These converts will learn more about fardhu ain such as tauhid, figh and moral throughout their stay in PUSBA (Lembaga Zakat Negeri Kedah, 2019). Other than that, LZNK estimated an allocation of RM150,000.00 to spend on the development of PUSBA. The new initiative introduced by LZNK seeks to ensure that the new converts are not involved in deviancy. According to al-Zuhaily (2004) this is one way how religious preservation as maslahah can be materialised.

According to Majid (2012), religion can be preserved by worshipping Allah and succumbing to the teaching of Islam. Thus, to ensure that the local people can learn religion as an act of worship, LZNK had set in 2019 to allocate a total of RM3,000,000.00 for the construction of mosques, musollas and religious schools. These institutions will act as religious institutions in spreading the teaching of Islam to all Muslims in Kedah. The determination of LZNK in preserving the maslahah of the religion is also proven with the allocation totalling RM2,200,000.00 in 2019 to Zakat Modern Hut and RM2,400,000.00 to Maahad Ad-Dini (Lembaga Zakat Negeri Kedah, 2019).

Maslahah of life maintenance is also given attention by LZNK. Thus, LZNK has targeted a scholarship for the year 2019 totalling RM2,393,500.00 to medical students who further studies locally and RM2,745,000.00 to medical students who further studies abroad (Lembaga Zakat Negeri Kedah, 2019). This large allocation is based on the fact that these students will serve the country as medical officers after they have finished their studies. In emergency situations where the baby's or the mother's life is at stake, medical experts would be necessary to undertake a treatment procedure. All the procedures are performed only by certified doctors. If a procedure goes against the shara', it will be allowed on the basis of saving lives and averting death, based on fiqh al-darurah tubih almahzurat (Abdullah, 2000).

Maslahah of preserving the mind can be done in various forms like admitting that the mind is the most crucial reward that can help us understand the signs of the supremacy of Allah SWT. The wisdom that can help us to think of various things will enable people to achieve all the good things and prevent themselves from any harm (al-Yubi, 1989). Thus, LZNK has introduced the Excellent Student Scheme where they will receive scholarship money every month. LZNK had allocated a total of RM972,000.00 in 2019 for this purpose (Lembaga Zakat Negeri Kedah, 2019).

Following al-Yubi (1989), among the ways of preserving one's generation is by taking care of the socialisation, giving birth to healthy babies from valid marriages and abortion is totally prohibited by syarak. Realising this, LZNK had prepared some allocation from the zakat money to medical students who study in the country and abroad. Although they are not religious students, they still get the allocation of zakat distribution on their expertise to achieve maslahah of preserving the generation (Lembaga Zakat Negeri Kedah, 2019). 
INTERNATIONAL JOURNAL OF ACADEMIC RESEARCH IN BUSINESS AND SOCIAL SCIENCES

Vol. 10, No. 7, July, 2020, E-ISSN: 2222-6990 @ 2020 HRMARS

\section{Maslahah Hajiyyah in the Education Zakat Distribution Practice}

Maslahah hajiyyah is a good deed that humans can live comfortably and they will be protected from any harm. All the difficulties will go away if maslahah hajiyyah can be achieved. The absence of maslahah hajiyyah will not threaten human life in terms of the religion, life, mind, generation and assets (al-Shatibi, 2011).

For this requirement, LZNK had targeted a total of RM180,000.00 as ticket fares assistance (Lembaga Zakat Negeri Kedah, 2019). According to al-Salam (t.t.) transportation is included in maslahah hajiyyah. Although transportation facilities can also be included under daruriyyah, flight facilities are included in hajiyyah only. It can solve the problem or difficulties faced by the students in their going out of, or returning to Malaysia. If the facility is not provided for, the students can still study in any higher learning institutions in the country.

LZNK also targeted an allocation of RM200,000.00 in 2019 as an allowance to industrial students (Lembaga Zakat Negeri Kedah, 2019). According to al-Shatibi (2011) maslahah hajiyyah has the role of supporting and completing the function of maslahah daruriyyah. Thus, these students will contribute to the development of the nation so that people will continue to live their lives without any hardships. All the basic necessities will be prepared and enjoyed by the society. This is due to the fact that the manufacturing of food, drinks and clothing will grow exponentially following students' involvement in the industry after they have completed their studies.

\section{Maslahah Tahsiniyyah in the Education Zakat Distribution Practice}

Al-Salam (t.t.) has defined maslahah tahsiniyyah as all the good deeds that lean on luxury and easy life, such as good food, expensive or branded clothes. Maslahah tahsiniyyah is something related to good moral nobility. All benefits that have not reached daruriyyat and hajiyyat will fall under the category of tahsiniyyah which is the category of luxury, complementary and has added value (alZubydi, 2014).

LZNK has realised maslahah tahsiniyyah in terms of the zakat education distribution. A total of RM600,000.00 was targeted by LZNK as the allocation in 2019 under the scheme called School Necessities Aid. Primary and secondary students in Kedah will receive school bags and uniforms (Lembaga Zakat Negeri Kedah, 2019). Such assistance will help students to have a better appearance and to be tidy when they go to school. According to al-Raysuni (2014), wearing something neat, beautiful and new is included in the category of maslahah tahsiniyyah. This is demanded by shara' and the objective is to achieve maslahah be it at daruriyyah, hajiyyah or even tahsiniyyah stage.

Apart from that, LZNK has targeted an allocation of RM2,500.000.00 in 2019 for Nidzomi Religious School (Lembaga Zakat Negeri Kedah, 2019). The aim is to prepare better infrastructure facilities to the school. The school environment will be more cheerful with this scheme. The deteriorating conditions of the school buildings and student hostels can be upgraded with more modern facilities. According to al-Salam (t.t.), owning beautiful and comfortable accommodation is also included in maslahah tahsiniyyah. 
INTERNATIONAL JOURNAL OF ACADEMIC RESEARCH IN BUSINESS AND SOCIAL SCIENCES

Vol. 10, No. 7, July, 2020, E-ISSN: 2222-6990 C 2020 HRMARS

\section{Diagram 1: The distribution of education zakat in LZNK According to the Maslahah}

- Maslahah that must be achieved by every individual at the expense of one's wellbeing and their daily survivability.

-UniSHAMS Scholarship

- Overseas Graduates' Donation -Public and Village Religious Teachers

- Medical Students' Scholarships

- Excellent Students' Scholarships
- Good deeds aim to make humans live comfortably and they will be prevented from any difficulties.

-Allowance for Overseas Trip Fares

-Allowance for Industrial Students

- Sponsorship of Ruyaq Jawi

-Mursyid Scholarship

-Assistance toPROSBA

\section{Hajiyah}

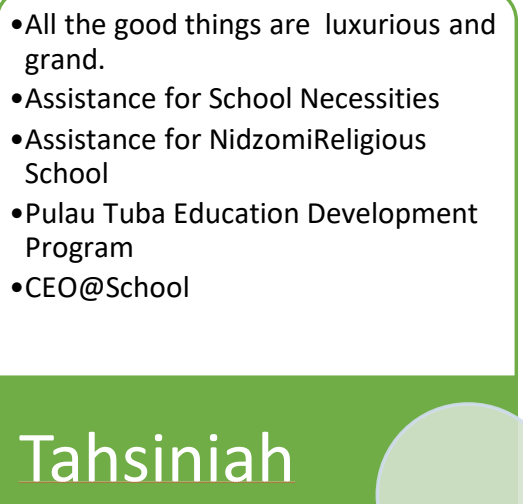

-All the good things are luxurious and grand.

-Assistance for School Necessities

ance for NidzomiReligious

Pulau Tuba Education Development

Program

Tahsiniah

\section{The Education Zakat Distribution Model in the Framework of Mas/ahah \& Social Principles}

Based on the zakat education distribution implemented by LZNK, clearly it is associated with the concept of maslahah that indirectly gives a positive impact to the Muslims especially in Kedah Darul Aman. This is in line with the definition of maslahah which linguistically means welfare (Adnan et al, 2017).

In the zakat education distribution to the asnaf, the maslahah approach must be comprehensive to get a positive impact and also to steer clear of the impending mafsadah (negative things or harm). Thus, al-Syatibi (2005) states that not all preservation of maslahah that is the mainstay of Syariah stays at the same level. Thus, the intended wellbeing in the zakat distribution is divided into three stages namely al-daruriyyah (necessity), al-hajiyyah (complimentary) and al-tahsiniyyah (embellishment). Thus, all these three stages of maqasid are complementary between one another and the aim must lean towards the welfare of the asnaf.

Other than that, al-tahsiniyyah is different from al-hajiyyah, as well as al-daruriyyah. Priority is given to al-daruriyyah. For example, an aid to the public religious school that does not gain any direct assistance from the government is prioritised more than the educational institution that receives assistance from the government. However, if there is any collision between al-tahsiniyyah and alhajiyyah, al-hajiyyah will be emphasised more. For instance, the travel fares abroad for students who further their studies to the Middle East will be emphasised more than uniform assistance to students who have obtained schooling assistance as there is a more pressing need to obtain the tickets.

Thus, if one of the al-hajiyyah or al-tahsiniyyah goes against al-daruriyyah, then daruriyyah is prioritised, such as scholarships to excellent students and medical students who are able to produce more successful asnaf children in future. Achieving al-tahsiniyyah is only feasible when the requirements for al-daruriyyah and al-hajiyyah are fulfilled such as undertaking academic improvement course also facilitating the development of educational institution to upgrade a more 
INTERNATIONAL JOURNAL OF ACADEMIC RESEARCH IN BUSINESS AND SOCIAL SCIENCES

Vol. 10, No. 7, July, 2020, E-ISSN: 2222-6990 @ 2020 HRMARS

comfortable facility like the education development special project in Tuba Island, Langkawi and CEO @ School.

Consistent with the al-maslahah al-mursalah approach adopted based on the al-munasib concept (which is appropriate) to benefit the zakat distribution to students in Egypt, starting from 2018 LZNK had taken an aggressive step by carrying out the zakat distribution based on their exam results although initially they had received some criticisms until there are asnaf who launched a protest in the Menara Zakat, Alor Star (Naim, 2019). The implication from this new term has invited a positive impact to students from Kedah who learn there including medical students as follows:

\begin{tabular}{r|lccc}
\multicolumn{2}{c}{ Item } & \multicolumn{2}{c}{2017} & \\
Mumtaz & No & Percent & No & Percent \\
\hline $\begin{array}{r}\text { (Excellent) } \\
\text { Jayyid Jiddan }\end{array}$ & 59 & $1 \%$ & 14 & $2 \%$ \\
(Very good) & & $3 \%$ & 113 & $7 \%$ \\
Jayyid (Good) & 130 & $8 \%$ & & $9 \%$ \\
Maqbul (Pass) & 268 & $17 \%$ & 146 & $19 \%$ \\
Rasib (Fail) & 1141 & $71 \%$ & 299 & $63 \%$
\end{tabular}

Table 3: The Exam Results of Kedah Students in Egypt After the New Terms of Zakat Distribution 2018

Based on Table 3, there is an increase for students who obtained mummtaz, jayyid jiddan, jayyid, and maqbul and a decrease in the number of students who obtained rasib (fail). This is in tandem with the fiqh proposal as follows:

To prevent a greater harm from happening, committing a smaller harm is thus, permissible (Zarqa', 1989)

When there are two damages, it is permissible to make a smaller damage with a smaller impact and lesser disadvantage (al-Suyuti, 1998).

Based on this, if individual harm is opposed to the societal harm, it is important that we remove the latter first. Thus, although initially there were protests from certain individuals who were not satisfied with this new rule, to ensure that the zakat distribution to benefit the society, although on the surface this is seen to be oppressing the students, it actually gives a good impact to them socially. This is because protecting the society also includes protecting individuals. In turn, if we are to protect only individuals, this might not protect the wellbeing of the society as a whole, especially when the fund for the zakat distribution is contributed by the people in the society.

Thus, rejecting mafsadah is compulsory to ensure the wellbeing of the society. Indirectly speaking, this principle gives a positive picture as to how Islam is really concerned about the public interests compared to individual's interests, especially when involving the mandate of the people such as the 
INTERNATIONAL JOURNAL OF ACADEMIC RESEARCH IN BUSINESS AND SOCIAL SCIENCES Vol. 10, No. 7, July, 2020, E-ISSN: 2222-6990 @ 2020 HRMARS

zakat fund. Thus, this is a very significant clue towards zakat institutions like LZNK in making decisions in carrying out the zakat distribution to those whoa re really qualified and so that the distribution is beneficial to the society.

The Conceptual Framework of the Education Zakat Distribution in The Maslahah and Social Principle Framework

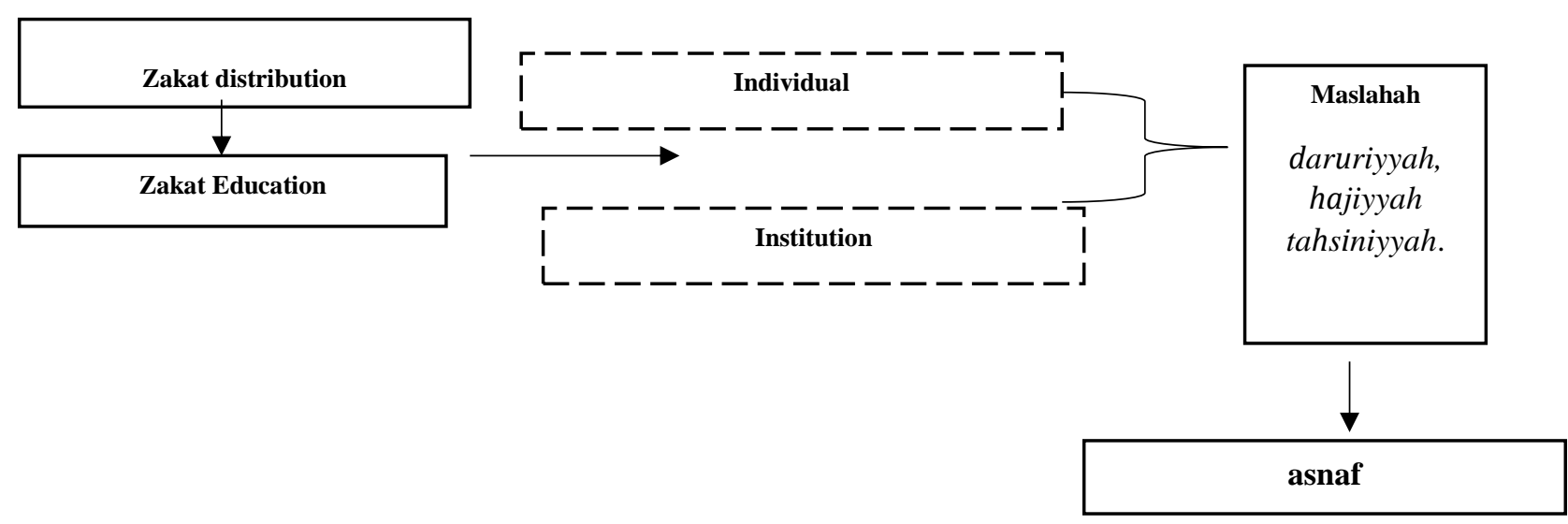

Diagram 2: The Conceptual Framework of The Education Zakat Distribution in The Maslahah And Social Principle Framework

\section{Conclusion}

Based on the above discussion, the conclusion that can be drawn is that the distribution of money under education zakat by LZNK is based on maslahah. Therefore, LZNK had allocated a huge amount of allocation for zakat money distribution on education which is an increase of $214 \%$ compared to the allocation in 2018. The money was used for the construction and the management of Pondok Moden Zakat totalled RM 2,200,000.00 and Maahad Dini, located in Alor Setar and Sik, received a total of RM 4,300,000.00. Other than that, a 100\% of an increased allocation in 2019 had been given to Converts' Guidance and Training Center (PUSBA), located in Sungai Petani with an amount of RM $2,000,000.00$.

In this issue, LZNK has applied the views held by al-Qardawi, Mahmud Syaltut and Rasyid Reda who have expanded the definition of fi sabilillah and students will be under the category fi sabilillah who are eligible to receive zakat (Al-Qardawi, 1973).Everything be it the cause, efforts and activities should aim to uphold and defend Allah's religion including the asnaf fi sabilillah (Lembaga Zakat Negeri Kedah, 2019). The construction of schools and universities using the zakat money must also be in line with the fatwa issued by the former Eqypt Mufti, Husnayn Makhluf. He issued the fatwa based on the definition of fi sabilillah according to al-Qaffal contained in a scripture written by al-Razi (Al-Qardawi, 1973). Accepting this opinion will be based on maslahah which is giving benefits to students and religious institutions. 
INTERNATIONAL JOURNAL OF ACADEMIC RESEARCH IN BUSINESS AND SOCIAL SCIENCES Vol. 10, No. 7, July, 2020, E-ISSN: 2222-6990 @ 2020 HRMARS

Other than that, LZNK also stresses more on the maslahah daruriyyah compared to maslahah hajiyyah and maslahah tahsiniyyah. A greater provision is given to the distribution of education zakat money in the category of maslahah daruriyyah. LZNK's action in chanelling zakat aid to religious institutions is also the basis of maslahah mursalah. Among the distributions for the institutions are the assistance for the Pondok Institutions, the sponsorship of Ruwaq Jawi, the construction of Rumah Anak Yatim Zakat and Kompleks Pembangunan Asnaf (Lembaga Zakat Negeri Kedah, 2019). This distribution does not coincide with the basic principle in the al-Quran and al-Sunnah. Thus, according to Khalaf (1996) maslahah that does not coincide with the evidence includes those in the category of maslahah mursalah. Meanwhile, LZNK's action is in line with the fiqhiyyah method, meaning: the administrators' action on the people is related to maslahah (al-Suyuti, 2018). In brief, all the actions done by LZNK in the education zakat distribution, it should be based on Educational Zakat Distribution Model in the framework of Maslahah and Social Principles where it is compulsory to ensure that the educational zakat distributions is done professionally and efficiently at the same time, there is an increase in zakat collection as the community begin to trust in zakat institution.

\section{Reference}

'Abd Allah, A. (2000). al-Rukhsah al-Syar'iyyah fi al-Usul wa al-Qawa'id al-Fiqhiyyah. Oman: Dar alKutub.

Ab Rahman, A., Alias, M. H., \& Omar, S. M. N. S. (2012). Zakat institution in Malaysia: Problems and issues. Global Journal of Al-Thalaqah, 2(1), 35-42.

Abidin, M. A. (2009). Agama bukan candu untuk mengkhayalkan orang miskin. Obtained from http://drmaza.com/home/?p=808

Abidin, M. A. (2010). Zakat berbaki atau kita kurang bijak membahagi. Obtained from http://drmaza.com/home/?p=1228

Adnan, N. I., \& Mamat, Z. (2017). Perakaunan Zakat Terhadap Manfaat Berupa Barangan (Benefit in Kind) Di Malaysia. Journal of Contemporary Islamic Law, 2(2): 24-34.

Al-Amidi, M. (1980). Al-Ihkam. Beirut: al-Maktab al-Islami.

Al-Ghazali, A. (1971). Al-Mustasfa min 'ilm al-usul. Beirut: Dar al-Kutub al-'Ilmiyyah.

Al-Qardawi, Y. (1973). Fiqh al-zakah. Beirut: Muassasah al-Risalah.

Al-Ramli, S. (2003). Nihayah al-Muhtaj ila Syarh al-Minhaj. Beirut: Dar al-Kutub al-'Ilmiyyah, 6:158

Al-Raysuni, A. (2014). Muhadarat fi Maqasid al-Shari'ah. Kaherah: Dar al-Kalimah.

Al-Sabuni, M. A. (2002). Mukhtasar Tafsir Ibn Kathir. Beirut: al-Maktabah al-Masriyyah.

Al-Salam A. M. (t.t.). Qawa'id al-Ahkam fi Masalih al-Anam. Kaherah: Maktabah al-Kulliyyat alAzhariyyah.

Al-Salam, M. (t.t.). Qawa'id al-Ahkam fi Masalih al-Anam. Kaherah: Maktabah al-Kulliyyat alAzhariyyah.

Al-Shatibi, A. I. (2011). al-Muwafaqat fi Usul al-Shari'ah. Kaherah: Dar al-Ghad Al-Hadid.

Al-Suyuti, A. (2018). al-Asybah Wa al-Nazair Fi Qawa'id Wa Furu'Fiqh al-Shafi'yyah. al-Qahirah: Dar al-Ghad al-Jadid.

Al-Yubi, M. S. (1989). Maqasid al-Shari'ah al-Islamiyyah. Riyadh: Dar al-Hijrah.

Al-Zubydi, B. (2014). al-ljtihad fi Manat al-Hukm al-Syar'i 'ind al-Usuliyyin Dirasah Ta'siliyyah Tatbiqiyyah. Saudi: Takwin li al-Dirasat Wa al-Abhath.

Al-Zuhaily, W. (1986). Usul al-Fiqh al-Islami. Beirut: Dar al-Fikr al-Mu'asir. 
INTERNATIONAL JOURNAL OF ACADEMIC RESEARCH IN BUSINESS AND SOCIAL SCIENCES Vol. 10, No. 7, July, 2020, E-ISSN: 2222-6990 @ 2020 HRMARS

Badarulzaman, M. H., \& Sulaiman, S. B. (2016). Undang-Undang Pentadbiran dan Pengurusan Zakat di Malaysia: Perbandingan Antara Enakmen Negeri-Negeri. In the 5th International Conference of Law and Society (ICLAS V). Kuala Terengganu: UNISZA.

Bahari, Z. (2010). Transformasi Penyaluran Produktif Berbentuk Bantuan Percuma Kepada Pengagihan Berbentuk lebih Bertanggungjawab: Kes Kajian di Pusat Urus Zakat, Pulau Pinang. Paper presented in The Forth ISDEV International Development Management Conference (IDMAC 2010), Zakat Transformation, organised by Pusat Kajian Pengurusan Pembangunan Islam (ISDEV), Pusat Pengajian Sains Kemasyarakatan, Universiti Sains Malaysia, Pulau Pinang, 21 and 21 December 2010.

Bahri, Z. (2014). Peranan Zakat Dalam Pendidikan Masyarakat Islam: Ulasan Kasus Zakat Pulau Pinang. Media Syariah, Vol XV1 No 1 June 2014.

Buang, A. H. (2000). Pengurusan zakat: satu analisis dari perspektif al-Quran dan al -Sunnah. Sharia Journal, 8(2): 89-102.

Ghazali, A. (1989). Fenomenon pembayaran zakat melalui saluran tidak rasmi - Satu analisis empirik. In Mohd Ali Hj. Baharum (Ed.), Zakat ditinjau dari perspektif sosial, undang-undang dan taksiran (pp. 1-27). Kuala Lumpur: Dewan Pustaka Islam.

Ibn al-Qayyim, M. (2001). I'lam al-Muwaqqi'in. Arab Saudi: Dar Ibn al-Jawzi.

Ibrahim, M. F., \& Musani, S. (2011). Zakat dan Pelaksanaannya di Malaysia. Kota Kinabalu: Universiti Malaysia Sabah.

Ibrahim, P. (2008). Pembangunan ekonomi melalui agihan zakat: Tinjauan empirikal. Jurnal Syariah, 16(2), 1-23.

Ismail, S. K. (2017). Penentuan Standard Maslahah dan Mafsadah Dalam Rawatan Materniti di Malaysia (PhD thesis, Universiti Malaya, Kuala Lumpur)

Khafildz, H. (2011). Fi Sabilillah Sebagai Medium Zakat Produktif, dlm Transfromasi Zakat: Daripada Zakat Saradiri Kepada Zakat Produktif. in Transformasi Zakat Daripada Zakat Saradiri Kepada Zakat Produktif, edited by Muhammad Syukri Salleh, Mohamad Salleh Abdullah \& Zahri Hamat, Pulau Pinang: Pusat Urus Zakat, Majlis Agama Islam Negeri Pulau Pinang, Pusat Kajian Pengurusan Pembangunan Islam (ISDEV), Universiti Sains Malaysia.

Khalaf, M. (1996). 'Ilm Usul al-Fiqh. Kaherah: Dar al-Fikr al-'Arabi.

Latif, M. D. A. (1998). Zakat management and administration in Malaysia. In Proceedings of Seminar of Zakat and Taxation.

Lembaga Zakat Negeri Kedah. (2018). Obtained from https://www.zakatkedah.com.my/profil-Iznk/ Lembaga Zakat Negeri Kedah. (2019). Obtained on 29 August 2019 from https://www.zakatkedah.com.my/Iznk-memperuntukkan-rm-6133000-00-bagi-tujuanbantuan-pendidikan/

Lembaga Zakat Negeri Kedah. (2019). Obtained on 29 August 2019 from https://www.zakatkedah.com.my/pelajar-sekolah-terima-manfaat-bantuan-pakaianseragam-sekolah-lznk/.

Lembaga Zakat Negeri Kedah. (2019). Obtained on 29 August 2019 from https://www.zakatkedah.com.my/pondok-moden-zakat-kedah

Lembaga Zakat Negeri Kedah. (2019). Obtained on 29 Ogos 2019 from https://www.zakatkedah.com.my/penerima-zakat

Majid, M. Z. A. (2012). Maqasid al-Shariah: Satu pengenalan. in Maqasid al-Syari'ah, ed. Mohmood Zuhdi Abdul Majid, Mek Work Mahmud dan Akhtarzaite Abdul Aziz, Selangor. UIAM Publisher. 
INTERNATIONAL JOURNAL OF ACADEMIC RESEARCH IN BUSINESS AND SOCIAL SCIENCES

Vol. 10, No. 7, July, 2020, E-ISSN: 2222-6990 @ 2020 HRMARS

Majid, M. Z. A. (2003). Pengurusan Zakat. Kuala Lumpur: Dewan Bahasa dan Pustaka

Md Hussain, M. H., \& Saad, R. A. J. (2012). Ketelusan Dalam Tadbir Urus Institusi Zakat. Prosiding Seminar Isu-Isu Kontemporari Zakat di Malaysia, organised by Pusat Islam Universiti Utara Malaysia on 25-27 November 2012.

Izam, M. Y. (2010). Pengurusan Zakat di Negeri Selangor: Mengorak Langkah Meneraju Perubahan. Zakat Transformation: From Subsistence to Productive. Paper work presented at the International Development Management Conference (IDMAC 2010), Universiti Sains Malaysia, 22 December. Malaysia: Penang.

Fadly, M. S. (2010). Lebih proaktif bantu si miskin, Harian Metro, pg. v4.

Farid, M. S. (2001). ABIM 30 tahun, beberapa isu penting sepanjang tiga dekad. Kuala Lumpur: Angkatan Belia Islam Malaysia.

Mokhtar, A. S. (2007). Paradigma Pengurusan Institusi Zakat: Pengalaman Lembaga Zakat Selangor (LZS) MAIS. Pemantapan Sistem Zakat dan Cukai ke Arah kemajuan Ekonomi Ummah. Paper work presented in the Persidangan Cukai dan Zakat Kebangsaan, Dewan Tun Dr. Ismail, PWTC, 23 May. Malaysia: Kuala Lumpur.

Mokhtar, A. S. (2007). Paradigma Pengurusan Institusi Zakat: Pengalaman Lembaga Zakat Selangor (MAIS), PWTC: Persidangan Cukai \& Zakat Kebangsaan, 2 May 2007.

Muhammad, Z. (2013). Al-Riqab: Tafsiran aplikasi semasa dari sudut Syarak. Jurnal Pengurusan JAWHAR, 6.

Muhammad, Z. (2013). Sejarah Hamba dan Kedudukan Ar-Riqab Sebagai Penerima Zakat Pada Masa Kini. Muzakarah Zakat Peringkat Kebangsaan series 1, 11 December 2013, Universiti Sains Islam Malaysia, Nilai, Negeri Sembilan.

Qaradawi, Y. (2000). Fiqh al-Zakah. Jeddah: Scientific Publishing Centre.

Rahman, A. A. R., \& Anwar, S. M. (2014). Zakat pendidikan kepada golongan asnaf di Malaysia Peranan dan cabarannya pada masa kini. Paper work presented in the International Conference on Masjid, Zakat and Waqf (IMAF 2014)1-2 December. Malaysia: Kuala Lumpur, 25-30.

Sadeq, A. H. M. (1995). Ethioco-eco-Institution of Zakah: An Instrument of Self-Reliance and Sustainable Grass-Root Development (Mimeograph).

Salleh, I., \& Ahmad, S. (2011). Indeks keyakinan terhadap lembaga zakat Selangor (LZS): Kajian kes kakitangan Universiti Kebangsaan Malaysia. Persidangan Kebangsaan Ekonomi Malaysia Ke VI (PERKEM VI), Malaysia. Retrieved from: http://www. ukm. my/fep/perkem/pdf/perkemVI/PERKEM2011-1-1B3. pdf.

Salleh, M. S. (2002). Lokalisasi Zakat: Satu Cadangan Teoritis. paper presented Muzakarah Pakar Zakat anjuran Fakulti Pengajian Islam, Universiti Kebangsaan Malaysia.

Sulong, J., \& Ali, A. M. (2012). KAJIAN PERBANDINGAN DALAM PENTADBIRAN UNDANG-UNDANG KUTIPAN ZAKAT DI PROVINSI ACEH DAN NEGERI KEDAH. Kajian Malaysia: Journal of Malaysian Studies, 30(1).

Tamuri, A. H. T., Shahrin, A., Kamarulzaman, A. G., Khadijah, A. R., Zarin, I., \& Aderi, M. C. N. (2006). Kajian amalan pengajaran guru pendidikan Islam di sekolah rendah dan menengah. Laporan penyelidikan, Universiti Kebangsaan Malaysia. IRPA 07-02-02- 10033EAR.

Tamuri, A. H., Khalthum, I., Nasruddin, Y., \& Azhar, A. (2007). Orientasi amalan agama dalam kalangan remaja Melayu: satu kajian di Negeri Johor. Laporan Penyelidikan ATMA, Universiti Kebangsaan Malaysia. 
INTERNATIONAL JOURNAL OF ACADEMIC RESEARCH IN BUSINESS AND SOCIAL SCIENCES

Vol. 10, No. 7, July, 2020, E-ISSN: 2222-6990 @ 2020 HRMARS

Utusan Online. (2001). Institusi zakat dipertikai. Accessed on Mei 25, 2011, from http://www.utusan.com.my/utusan/info.asp?y=2001\&dt=1203\&pub=Ut usan_Malaysia\&sec=Muka_Hadapan\&pg=mh_01.htm

Wahab, N. A., \& Abdul-Rahman, A. R. A. (2015). Efficiency of zakat institutions and its determinants. Access to Finance and Human Development-Essays on Zakah, Awqaf and Microfinance, 33.

Wahab, N. A., \& Rahman, A. R. A. (2013). Determinants of efficiency of zakat institutions in Malaysia: A non-parametric approach. AJBA, 6(2): 33-58.

Wahid, H., Ahmad, S. \& Kader, R. (2009). Zakat distribution oleh Institusi Zakat di Malaysia: Mengapakah Masyarakat Islam Tidak Berpuashati? Sharia Journal, 17(1): 89-112.

Zaki M., Sulong, J. (2019). Aplikasi Strategi Lautan Biru Kebangsaan Dalam Zakat education distributiondi Zakat Pulau Pinang (ZPP). UMRAN International Journal of Islamic and Civilizational Studies. 6(2), 55-72.

\section{Interview}

Interview with Faisal Mustaffa, Deputy Head of Executive Officers of Lembaga Zakat Negeri Kedah and Mohd Norhaizzat Naim Mohd Mazlan, Head of the Education and Innovation Department, at Menara Zakat, Alor Setar on Sunday 26 May 201910 am. 